\title{
South polar skuas from a single breeding population overwinter in different oceans though show similar migration patterns
}

\author{
Matthias Kopp ${ }^{1}$, Hans-Ulrich Peter ${ }^{1, *}$, Osama Mustafa ${ }^{1,2}{ }^{,}$, Simeon Lisovski ${ }^{1}$, \\ Markus S. Ritz ${ }^{1,3}$, Richard A. Phillips ${ }^{4}$, Steffen Hahn ${ }^{5}$ \\ ${ }^{1}$ Institute of Ecology, Friedrich-Schiller University, 07743 Jena, Germany \\ ${ }^{2}$ Thuringian Institute for Sustainability and Climate Protection, 07743 Jena, Germany \\ ${ }^{3}$ Senckenberg Museum of Natural History, 02826 Görlitz, Germany \\ ${ }^{4}$ British Antarctic Survey, Natural Environment Research Council, Cambridge CB3 0ET, UK \\ ${ }^{5}$ Swiss Ornithological Institute, CH-6204 Sempach, Switzerland
}

\begin{abstract}
Seabirds in seasonal environments are often long-distance migrants and, for many species and populations, their ranges throughout the non-breeding period are unknown. As conditions during the non-breeding season often affect subsequent performance, the choice of migration strategy can have major implications for timing of breeding and success and, ultimately, population dynamics. We tracked south polar skuas Catharacta maccormicki from a single breeding population at King George Island in the South Shetland Islands (Antarctica). Overall, 27 birds (69\%) migrated to the northern Atlantic (3 regions), 10 birds ( $26 \%$ ) to the northern Pacific Ocean (2 regions), and 2 birds wintered in the southern hemisphere. Individuals tracked in consecutive non-breeding seasons chose the same ocean for wintering. Despite migrating to different oceans, birds showed a similar figure-ofeight flight pattern and equivalent residency periods in the main wintering areas. In addition, $87 \%$ of the migrants used terminal stop-over sites off South America shortly before returning to the breeding site. High diversity of migration patterns may buffer south polar skuas from climate change and other anthropogenic threats.
\end{abstract}

KEY WORDS: Migratory connectivity $\cdot$ Annual cycle $\cdot$ Seabird $\cdot$ Antarctic $\cdot$ Pacific $\cdot$ Trans-equatorial $\cdot$ Geolocator Resale or republication not permitted without written consent of the publisher

\section{INTRODUCTION}

Avian migration is driven primarily by seasonality in environmental conditions, especially food availability (Berthold et al. 2003). Amongst pelagic seabirds, there are many long-distance, and some trans-equatorial migrants (Shaffer et al. 2006, González-Solís et al. 2007, Egevang et al. 2010). The availability of marine resources varies considerably in space and time, and foraging seabirds concentrate in the areas of highest prey abundance and predictability (Dingle 1996, Shaffer et al. 2006). Migrants therefore often target continental shelf waters, shelf slopes and upwellings, and other frontal systems (Phillips et al. 2006, GonzálezSolís et al. 2007, Guilford et al. 2009). There is growing evidence that migration patterns are more variable in time and space than previously anticipated and, at least in birds, that they can change rapidly when conditions alter (Pulido et al. 2001, Quillfeldt et al. 2010, Dias et al. 2011). Thus, determining current levels of variation between individuals and populations is fundamental to predicting the flexibility and potential future viability of species facing unprecedented global changes in climate and other environmental characteristics.

South polar skuas Catharacta maccormicki are longlived predatory seabirds that breed in coastal Antarctica and on adjacent islands. On the basis of observations at sea and along the coast of North America and northwest Africa, this species was thought to undertake a trans-equatorial migration (Furness 1987, Olsen 
\& Larsson 1997). However, in the absence of tracking data, there were no studies of the routes or wintering destinations used by specific breeding populations. The purpose of this study was to determine intrapopulation variability in migration patterns of south polar skuas breeding on King George Island, which might theoretically overwinter in either the Pacific or Atlantic oceans.

\section{MATERIALS AND METHODS}

We equipped 58 adult south polar skuas $(27$ females, 29 males, 2 unknown sex) with light recording geolocators (British Antarctic Survey, Cambridge) during 3 breeding seasons (2006-2008) at King George Island in the Maritime Antarctic $\left(62^{\circ} 12^{\prime} \mathrm{S}, 58^{\circ} 58^{\prime} \mathrm{W}\right)$. The geolocators (MK5 and MK9) weighed 9.4 and $8.2 \mathrm{~g}$ including the steel ring, respectively, which corresponded to ca. $0.8 \%$ of the mean adult body mass. Thirty-nine individuals (18 females, 20 males, 1 unknown sex; all birds were later genetically sexed, Fridolfsson \& Ellegren 1999) were recaptured at the same breeding site during consecutive seasons until 2010, resulting in 52 annual tracks. Re-sighting rate did not differ between equipped birds (83\%) and breeding birds without a device $(78 \%$, logistic regression, Wald $=7.28, \mathrm{p}=0.393$ ). Two positions per day were calculated from light measurements using TransEdit and BirdTracker software (British Antarctic Survey, Cambridge), based on a standard approach (Phillips et al. 2006). Positions that were derived from interrupted light curves around dawn or dusk, that were close to equinoxes, or were obviously erroneous, were excluded, resulting in an average of $331 \pm 25$ val- idated positions/individual/season. Each data set was split into periods of movement and residency; the latter defined by positions which were both preceded and succeeded by 2 other positions that were within a circle of $400 \mathrm{~km}$ radius (Bächler et al. 2010). Thereafter, we applied kernel density analysis to locations during residency periods in order to highlight wintering and staging areas (ESRI ArcGIS 9.3, search radius: $500 \mathrm{~km}$, output cell size: $200 \mathrm{~km}$ ). Timing of departure and arrival refer to the date a bird crossed the boundary of the $95 \%$ Contour Volume Plot (Beyer 2004). The geographical coordinates were transformed to the World Winkel Tripel reference system prior to working with geodata. Statistical analyses were performed in SPSS 16.0. Tests were 2 -tailed and the presented values are mean $\pm \mathrm{SD}$, unless stated otherwise.

\section{RESULTS}

During the non-breeding season, south polar skuas from King George Island migrated either into the Atlantic $(72 \%, \mathrm{n}=28)$ or the Pacific Ocean $(28 \%, \mathrm{n}=$ 11). There was no sex-specific preference for a particular ocean $\left(\chi^{2}=0.77, p=0.68\right)$. Choice of ocean was consistent over 2 or 3 consecutive years $(\mathrm{n}=11)$.

All birds showed a similar general structure to the migration in that they spent a long period of residency in the most northerly portion of the journey, i.e. in the main wintering area, and used several short staging areas during the autumn and spring migration. Ninety-two percent of individuals overwintered in the northern hemisphere at $>30^{\circ} \mathrm{N}_{i}$ the remaining 2 individuals stayed in the southern hemisphere off Peru and west of Gough Island (Table 1). Trans-equatorial

Table 1. Catharacta maccormicki. Characteristics of individual wintering areas of south polar skuas from a single breeding population on King George Island. Areas and time periods are based on size and residency periods within the $95 \%$ Volume Contour. Number of staging sites used during north- (autumn) and southbound (spring) migrations; number of tracks and numbers of each sex are also given

\begin{tabular}{|c|c|c|c|c|c|c|c|c|}
\hline Ocean & Wintering area & Geographical range & $\begin{array}{c}\text { Area } \\
\left(\times 10^{5} \mathrm{~km}^{2}\right)\end{array}$ & $\begin{array}{l}\text { Period } \\
\text { (d) }\end{array}$ & $\begin{array}{l}\text { Stagin } \\
\text { Northbound }\end{array}$ & Southbound & Tracks & $\begin{array}{l}\text { Male/ } \\
\text { female }\end{array}$ \\
\hline \multirow[t]{3}{*}{$\begin{array}{l}\text { Northern } \\
\text { Atlantic }\end{array}$} & Newfoundland Basin & $38-47^{\circ} \mathrm{N}, 30-50^{\circ} \mathrm{W}$ & $25.5 \pm 6.1$ & $109 \pm 2$ & $2.5 \pm 0.8$ & $2.6 \pm 1.0$ & 34 & $\begin{array}{c}\text { 12/12 + } \\
1 \text { unknown }\end{array}$ \\
\hline & South of Georges Bank & $35-43^{\circ} \mathrm{N}, 60-69^{\circ} \mathrm{W}$ & $16.1 \pm 0.1$ & $89 \pm 8$ & $3.5 \pm 0.7$ & $3.0 \pm 1.4$ & 2 & $0 / 1$ \\
\hline & $\begin{array}{l}\text { Cape Verde Plateau } \\
\text { off Mauritania }\end{array}$ & $15-22^{\circ} \mathrm{N}, 16-19^{\circ} \mathrm{W}$ & 14.5 & 96 & 3 & 1 & 1 & $0 / 1$ \\
\hline $\begin{array}{l}\text { Southern } \\
\text { Atlantic }\end{array}$ & West of Gough Island & $40-50^{\circ} \mathrm{S}, 0-15^{\circ} \mathrm{W}$ & 28.6 & 213 & 0 & 0 & 1 & $1 / 0$ \\
\hline Northern & Northwest of Hawaiian Ridge & $30-40^{\circ} \mathrm{N}, 165^{\circ} \mathrm{W}-165^{\circ} \mathrm{E}$ & $28.8 \pm 4.5$ & $112 \pm 9$ & $1.8 \pm 1.3$ & $2.7 \pm 1.2$ & 6 & $2 / 2$ \\
\hline Pacific & $\begin{array}{l}\text { South of Gulf of Alaska } \\
\text { Hawaiian Ridge and Gulf of } \\
\text { Alaska }\end{array}$ & $45-55^{\circ} \mathrm{N}, 135-150^{\circ} \mathrm{W}$ & $\begin{array}{l}31.7 \pm 9.4 \\
42.3 \pm 4.4\end{array}$ & $\begin{array}{l}109 \pm 1 \\
111 \pm 6\end{array}$ & $\begin{array}{l}3.0 \pm 0.0 \\
1.6 \pm 1.4\end{array}$ & $\begin{array}{l}3.0 \pm 1.4 \\
3.8 \pm 0.8\end{array}$ & $\begin{array}{l}2 \\
5\end{array}$ & $\begin{array}{l}1 / 1 \\
2 / 2\end{array}$ \\
\hline $\begin{array}{l}\text { Southern } \\
\text { Pacific }\end{array}$ & Off Peru & $13-22^{\circ} \mathrm{S}, 76-80^{\circ} \mathrm{W}$ & 18.4 & 111 & 2 & 1 & 1 & $1 / 0$ \\
\hline
\end{tabular}


migrations showed a figure-of-eight pattern in both flyways (Fig. 1). Individual wintering areas in the North Atlantic were smaller than in the North Pacific $\left(24.6 \pm 6.5 \times 10^{5} \mathrm{~km}^{2}\right.$ and $34.6 \pm 8.2 \times 10^{5} \mathrm{~km}^{2}$, respectively; $F_{1,49}=19.6, \mathrm{p}=0.001$ ). Mean residency period in the main wintering area of each bird was $109 \pm$ $18.4 \mathrm{~d}$, with no significant difference between oceans $\left(F_{1,49}=0.30, \mathrm{p}=0.59\right)$.

Birds using the Atlantic flyway departed on a bearing of $350^{\circ}$ from their breeding site and migrated in a broad corridor parallel to the east coast of South America. After crossing the equator, south polar skuas mainly changed to a northwesterly heading, although one bird continued to its wintering area off the coast of Mauritania. On the northward migration, south polar skuas stopped at 3 staging sites (median; range: 1 to 4 ) and arrived at the main wintering area on 24 May (average; range: 7 May to 4 June). Birds subsequently moved eastwards by $1240 \mathrm{~km}$ (median). The return migration started on 5 September (average; range: 22 August to 3 November). Birds departing from the east Atlantic (at ca. $10^{\circ} \mathrm{W}$ ) travelled to the west coast of Africa, and when south of $10^{\circ} \mathrm{N}$, headed southwest towards Brazil, whereas birds starting from the mid-Atlantic flew directly to this region. Both groups subsequently travelled south parallel to the South American coast, and all stopped in waters of the Patagonian shelf $\left(30\right.$ to $50^{\circ} \mathrm{S}$, 30 to $60^{\circ} \mathrm{W}$ ) for up to $22 \mathrm{~d}$ (median: $10 \mathrm{~d}$ ) before returning to the Antarctic. While travelling south, birds typically used 3 staging areas (median; range: 1 to 5, comparison between north- and southward migration: paired $t$-test: $t=-0.26, \mathrm{df}=37, \mathrm{p}=0.79$ ).

Birds using the Pacific flyway left the breeding site on a bearing of ca. $300^{\circ}$ and migrated along the west coast of South America. After passing $30^{\circ} \mathrm{S}$, they headed northwest towards Hokkaido. South polar skuas arrived in the primary wintering area on 14 May (average; range: 28 April to 27 May), which was significantly earlier than the mean arrival date at the equivalent area in the North Atlantic $\left(F_{1,49}=21.5, \mathrm{p}=0.001\right)$, even though the numbers of stopovers were similar (median: 2, range: 0 to 4, Mann-Whitney test: $Z=-1.82$, $p=0.07$ ). Birds wintering northwest of the Hawaiian Ridge moved west by $965 \mathrm{~km}$ (median), whereas those using the 2 North Pacific wintering sites moved east by $3320 \mathrm{~km}$ (median). All began the return migration on

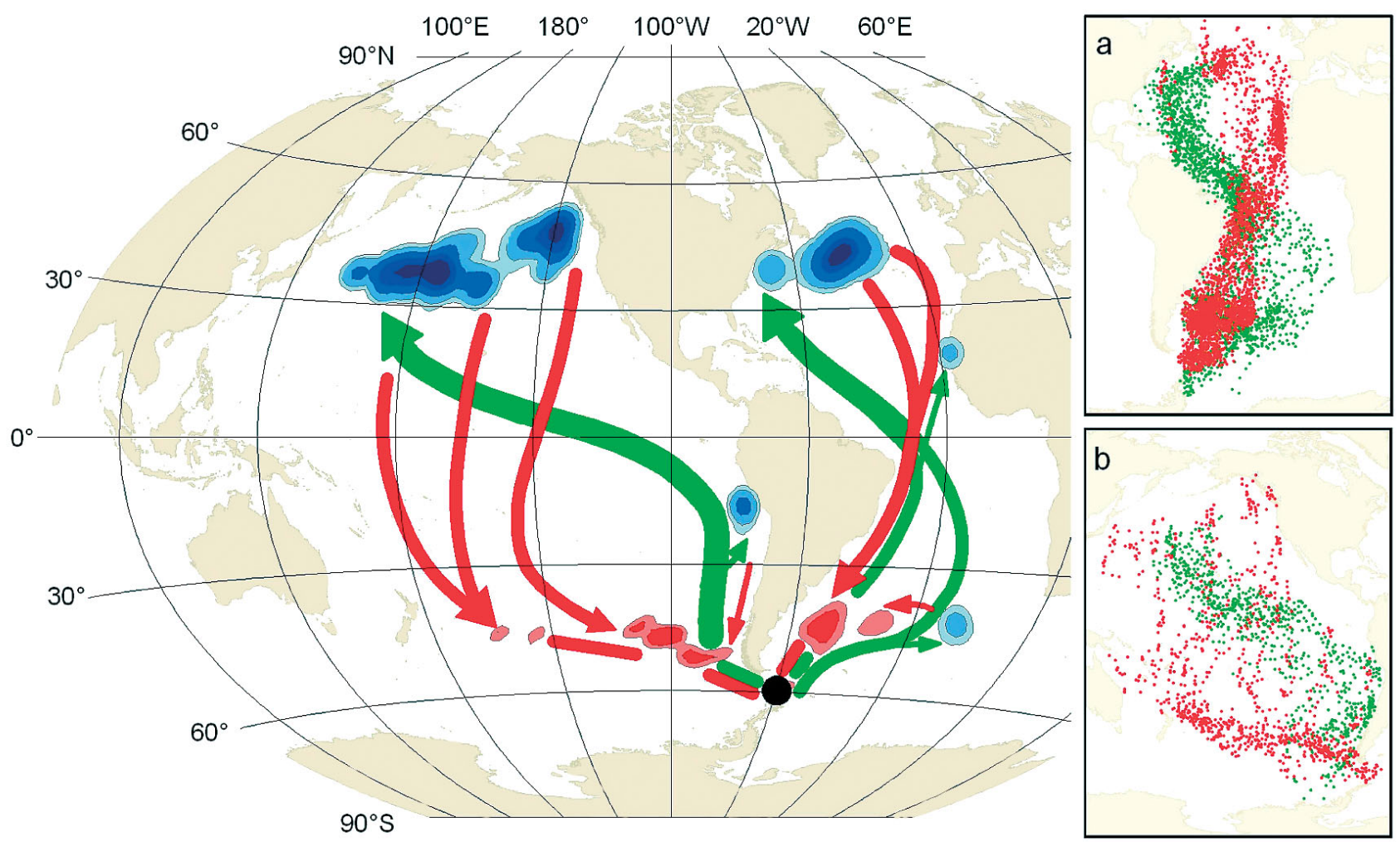

Fig. 1. Catharacta maccormicki. Wintering areas and migration routes of south polar skuas breeding at King George Island (๑). Wintering areas are displayed as blue Percent Volume Contours $(25,50,75,90$, and $95 \%$ probability of presence) based on kernel density estimation; red contours are terminal staging areas (25 and 50\%). Autumn migration routes and individual locations are shown in green; spring migration and individual locations in red. Kernels were calculated for each flyway separately. Samples sizes are $n=28$ (Atlantic) and $n=11$ (Pacific). Insets display the valid locations in the (a) Atlantic and (b) Pacific 
30 August (average; range: 23 August to 2 September). The spring migration was more complex: most birds $(\mathrm{n}=9)$ started from the central North Pacific and the Alaskan basin and travelled in a wide circle south and southwest to waters north of New Zealand and Australia, then turned east-southeast towards the Antarctic Peninsula. Three others departed from the Alaskan basin and flew directly south and then turned eastsoutheast at ca. $40^{\circ} \mathrm{S}$. Birds used more staging areas (median: 3, range: 2 to 5) on the southward than the northward migration (paired $t$-test: $t=-2.16, \mathrm{df}=13$, $\mathrm{p}=0.05)$. Similar to birds in the Atlantic flyway, 7 individuals (64\%) spent some time (median: $3.5 \mathrm{~d}$, range: 1 to $12 \mathrm{~d}$ ) in a pre-breeding staging site off southern South America, at 40 to $60^{\circ} \mathrm{S}, 70$ to $11^{\circ} \mathrm{W}$, before returning to the breeding site.

\section{DISCUSSION}

In this, the first tracking study of south polar skuas, we found a striking degree of variability in migration strategies within a single population. This included trans-equatorial migration of most birds to the far North Pacific or North Atlantic, and of one bird to the coast of Mauritania, along with considerably shorter migrations by single individuals to waters either off Peru or in the central South Atlantic. Despite the disparate primary winter destinations, the trans-equatorial migrants showed a common structure to their movements, with figure-of-eight routes used in both oceans, equivalent periods of residency in the main wintering areas and comparable numbers of stopover sites. In addition, almost all used a terminal staging somewhere in South American waters during the immediate pre-breeding period.

The individual south polar skuas which spent the winter in waters of the southern hemisphere were exceptional for our studied population. Because the closely related brown skua Catharacta antarctica lonnbergi overwinter in the southern ocean (Phillips et al. 2007), and hybridize with south polar skua in our study area (Ritz et al. 2006), the 2 focal specimens could be hybrids between both skua species. However, a posthoc discriminant analysis including 33 south polar skuas, 16 brown skuas and 9 hybrids (taxa identity was established genetically, Ritz 2009), confirmed a $90 \%$ probability for classification as south polar skuas for both individuals.

The figure-of-eight flight pattern used by the south polar skuas is similar to that recently described for Arctic terns Sterna paradisea which migrated from a breeding site in Greenland to Antarctica (Egevang et al. 2010). Elements of this pattern are also reflected in some movement phases of other North Atlantic sea- birds that are trans-equatorial migrants (Guilford et al. 2009). In general, it has been assumed that such a pattern is dictated by the Coriolis force (Shaffer et al. 2006) and the exploitation of global wind circulation by birds to reduce flight costs (Felicisimo et al. 2008). In contrast, the longitudinal movements within the wintering areas were more likely to be caused by the west-east orientation of ocean currents in the North Atlantic (Gulf Stream, North Atlantic Drift) and North Pacific (North Pacific Drift) and the West Wind Drift at this latitude.

On the return (spring) migration, almost all individuals stopped in terminal staging areas in the Pacific or Atlantic off the South American coast that were ca. $3000 \mathrm{~km}$ from the Antarctic breeding site (Fig. 1). Along their flyway, ocean waters differ largely in primary production with low productivity areas, i.e. the big gyres in the Pacific and Atlantic (Mather et al. 2008, D'Hondt et al. 2009), and very productive areas, i.e. the Brazil-Malvinas Confluence Zone in the Argentina Basin (Behrenfeld \& Falkowski 1997, Pfeifer et al. 2001) and the cold water of the South Pacific Current. Therefore, we can assume that south polar skuas used the terminal staging sites at about $50^{\circ} \mathrm{S}$ to recover body condition lost during the energeticallydemanding southern migration through the comparatively unproductive tropical waters shortly before they return to breed.

The extensive wintering range and diversity of migration routes recorded in this study suggests that south polar skuas experience a wide range of environmental conditions during the non-breeding season, as oceanography and climatic oscillations differ fundamentally between the North Pacific and North Atlantic (Stenseth et al. 2003). This suggests a degree of flexibility in terms of habitat requirements, which might buffer this species from possible adverse effects of future climate change or other anthropogenic threats in wintering grounds. Nevertheless, as conditions experienced during one stage of the annual cycle can have repercussions (Harrison et al. 2011), the adoption of a particular migration strategy may affect body condition on return to the colony, laying date, breeding success or survival (Marra et al. 1998, Robb et al. 2008). If this is the case, temporal changes in environmental conditions will mean that certain strategies will offer a selective advantage. Assuming spatio-temporal migration patterns are heritable this may have strong implications for population dynamics and genetic structure in the future.

Acknowledgements. This project was funded by the DFG (PE 454/16) and supported by private sponsors. This paper represents a contribution to the British Antarctic Ecosystems programme. A. Fröhlich and J. Esefeld helped in the field. 


\section{LITERATURE CITED}

Bächler E, Hahn S, Schaub M, Arlettaz R and others (2010) Year-round tracking of small trans-saharan migrants using light-level geolocators. PLoS ONE 5(3):e9566 doi:10.1371/ journal.pone.0009566

Behrenfeld MJ, Falkowski PG (1997) Photosynthetic rates derived from satellite-based chlorophyll concentration. Limnol Oceanogr 42:1-20

Berthold P, Gwinner E, Sonnenschein E (2003) Avian migration. Springer, Berlin

Beyer HL (2004) Hawth's analysis tools for ArcGIS. www. spatialecology.com/htools

D'Hondt S, Spivack AJ, Pockalny R, Ferdelman TG and others (2009) Subseafloor sedimentary life in the South Pacific Gyre. Proc Natl Acad Sci USA 106:11651-11656

Dias MP, Granadeiro JP, Phillips RA, Alonso H, Catry P (2011) Breaking the routine: individual Cory's shearwaters shift winter destinations between hemispheres and across ocean basins. Proc Biol Sci 278:1786-1793

Dingle H (1996) Migration: the biology of life on the move. Oxford University Press, New York, NY

Egevang C, Stenhouse IJ, Phillips RA, Petersen A, Fox JW, Silk JRD (2010) Tracking of Arctic terns Sterna paradisaea reveals longest animal migration. Proc Natl Acad Sci USA 107:2078-2081

Felicisimo AM, Munoz J, Gonzalez-Solis J (2008) Ocean surface winds drive dynamics of transoceanic aerial movements. PLoS ONE 3(8):e2928 doi:10.1371/journal.pone.0002928

Fridolfsson AK, Ellegren H (1999) A simple and universal method for molecular sexing of non-ratite birds. J Avian Biol 30:116-121

Furness RW (1987) The skuas, 1st edn. T \& AD Poyser, Carlton, OR

González-Solís J, Croxall JP, Oro D, Ruiz X (2007) Transequatorial migration and mixing in the wintering areas of a pelagic seabird. Front Ecol Environ 5:297-301

Guilford T, Meade J, Willis J, Phillips RA and others (2009) Migration and stopover in a small pelagic seabird, the Manx shearwater Puffinus puffinus: insights from machine learning. Proc Biol Sci 276:1215-1223

Harrison XA, Blount JD, Inger R, Norris DR, Bearhop S (2011) Carry-over effects as drivers of fitness differences in animals. J Anim Ecol 80:4-18

Marra PP, Hobson KA, Holmes RT (1998) Linking winter and

Editorial responsibility: Matthias Seaman,

Oldendorf/Luhe, Germany summer events in a migratory bird by using stable-carbon isotopes. Science 282:1884-1886

Mather RL, Reynolds SE, Wolff GA, Williams RG and others (2008) Phosphorus cycling in the North and South Atlantic Ocean subtropical gyres. Nat Geosci 1:439-443

Olsen KM, Larsson H 1997. Skuas and jaegers: a guide to the skuas and jaegers of the world. Pica Press, Mountfield

Pfeifer K, Kasten S, Hensen C, Schulz HD (2001) Reconstruction of primary productivity from the barium contents in surface sediments of the South Atlantic Ocean. Mar Geol 177:13-24

Phillips RA, Silk JRD, Croxall JP, Afanasyev V (2006) Yearround distribution of white-chinned petrels from South Georgia: relationships with oceanography and fisheries. Biol Conserv 129:336-347

> Phillips RA, Catry P, Silk JRD, Bearhop S, McGill R, Afanasyev V, Strange IJ (2007) Movements, winter distribution and activity patterns of Falkland and brown skuas: insights from loggers and isotopes. Mar Ecol Prog Ser 345: 281-291

Pulido F, Berthold P, Mohr G, Querner U (2001) Heritability of the timing of autumn migration in a natural bird population. Proc Biol Sci 268:953-959

Quillfeldt P, Masello JF, McGill RAR, Adams M, Furness RW (2010) Moving polewards in winter: A recent change in the migratory strategy of a pelagic seabird? Front Zool 7:15

Ritz MS (2009) Speciation and hybridisation in skuas (Catharacta ssp.). PhD thesis. Friedrich-Schiller-University, Jena. www. db-thueringen.de/servlets/DocumentServlet?id=12901

Ritz MS, Hahn S, Janicke T, Peter HU (2006) Hybridisation between South polar skua (Catharacta maccormicki) and Brown skua $(C$. antarctica lonnbergi) in the Antarctic Peninsula region. Polar Biol 29:153-159

> Robb GN, McDonald RA, Chamberlain DE, Reynolds SJ, Harrison TJE, Bearhop S (2008) Winter feeding of birds increases productivity in the subsequent breeding season. Biol Lett 4:220-223

Shaffer SA, Tremblay Y, Weimerskirch H, Scott D and others (2006) Migratory shearwaters integrate oceanic resources across the Pacific Ocean in an endless summer. Proc Natl Acad Sci USA 103:12799-12802

Stenseth NC, Ottersen G, Hurrell JW, Mysterud A and others (2003) Studying climate effects on ecology through the use of climate indices: the North Atlantic Oscillation, El Nino Southern Oscillation and beyond. Proc Biol Sci 270:2087-2096

Submitted: May 24, 2011; Accepted: May 25, 2011

Proofs received from author(s): July 28, 2011 